\title{
Antibacterial Activity and Mode of Action of Black Mulberry (Morus nigra) Fruits Extract Against Streptococcus mutans
}

\author{
Arif Budiman', Diah Lia Aulifa ${ }^{2, *}$
}

\section{Arif Budiman', Diah Lia Aulifa ${ }^{2, *}$}

'Department of Pharmaceutics and Pharmaceutical Technology, Faculty of Pharmacy, Universitas Padjadjaran, Jl. Raya Bandung-Sumedang Km. 21. INDONESIA. ${ }^{2}$ Department of Pharmaceutical Biology, Sekolah Tinggi Farmasi Indonesia (Indonesian School of Pharmacy), Jl. Soekarno-Hatta No 354, Bandung 40266, West Java, INDONESIA.

\section{Correspondence}

\section{Diah Lia Aulifa}

Department of Pharmaceutical Biology, Sekolah Tinggi Farmasi Indonesia

(Indonesian School of Pharmacy), JI.

Soekarno-Hatta No 354, Bandung 40266

West Java, INDONESIA.

E-mail: diahliaaulifa@gmail.com

History

- Submission Date:14-08-2020;

- Review completed: 13-09-2020;

- Accepted Date: 16-09-2020

DOI : 10.5530/pj.2020.12.233

Article Available online

http://www.phcogj.com/v12/i6s

\section{Copyright}

(c) 2020 Phcogj.Com. This is an openaccess article distributed under the terms of the Creative Commons Attribution 4.0 International license.

\begin{abstract}
Background: Black mulberry was a member of the plant groups from genus Morus, which contains the highest total phenolic compounds compared to other species. It could be a potential source of antimicrobial agents. Therefore, this study aimed to evaluate the antibacterial activity of the fruits extract against Streptococcus mutans. Methods: Agar diffusion and microdilution methods were used for evaluation of the antibacterial activity and the minimum inhibitory concentration (MIC) of the extract. Protein and ion leakage from the bacterial cells induced by the extract was analyzed spectrophotometrically. The morphological change was determined using Scanning electron microscopy (SEM). Result: Black mulberry (BM) fruits extract showed antibacterial activity against $S$. mutans with $\mathrm{MIC}$ value of $8 \mathrm{mg} / \mathrm{mL}$, as well as contributed to the aforementioned leakage. Meanwhile, cellular membrane damage was observed, indicating that the extract might inhibit growth of the bacteria. Conclusion: BM extract could be a potential raw material for herbal medicine, especially anticaries which has antibacterial activity.
\end{abstract}

Keywords: black mulberry fruits extract, Streptococcus mutans, cellular membrane damage

\section{INTRODUCTION}

Morus or mulberry is the genus of plants belonging to the Moraceae family. They are widely grown in subtropic regions of Asia, Africa, and North America. ${ }^{1}$ The fruits were commonly used as food ingredients such as juices, wines, and jams. ${ }^{2}$ Various parts of the plants could also be used as cosmetic products and herbal medicines. ${ }^{3}$ In addition, flavonoids, polyhydroxylated alkaloids, and benzofurans are the most representative bioactive compounds that have been identified from the root of mulberry. ${ }^{4}$ The extract have shown several pharmacological activities, which include antimicrobial, anti-inflammatory, antifungal, antioxidant, skin-whitening, anticancer, antidiabetic, anti-hyperlipidemic, anti-platelet, and immunomodulation. ${ }^{5,6}$

Black mulberry belongs to the genus Morus, which contains the highest total phenolic compounds compared to other species. ${ }^{7,8}$ Furthermore, the extract exhibited an antibacterial effect on Staphylococcus aureus, Staphylococcus epidermidis and Propionibacterium acnes. ${ }^{10,11}$ The fruits are a rich source of flavonoids and anthocyanins which can be used for antioxidation. ${ }^{8,11}$ Souza et al reported that black mulberry extract has strong antioxidant and antibacterial activities as well as weak cytotoxic effects. ${ }^{12}$

Streptococcus mutans are gram-positive bacteria commonly found in the human oral cavity and are the main contributor to tooth decay, ${ }^{13}$ while pharynx, mouth, and intestine are the primary habitats. ${ }^{14}$ In addition, they can act as strong acid producers together with lactobacilli, causing the risk for cavities. ${ }^{16} S$. mutans and Streptococcus sobrinus can cause dental caries because of the ability to adhere to enamel salivary pellicle. ${ }^{15}$

Several studies have reported the antibacterial activity of the BM extract. However, the mechanism involved in this process has not been clearly understood. In this study, antibacterial activity of the extract against S. mutans was evaluated using the micro-dilution method. Then, analysis of protein, nucleic acid, and ion leakage, as well as cell morphological observation were also investigated.

\section{MATERIAL AND METHOD}

\section{Materials}

Black mulberry (BM) fruits were obtained from Cibodas, Maribaya-Lembang, and authenticated by the Department of Biology, Faculty of Science, Universitas Padjadjaran, Bandung, Indonesia. In addition, Muller Hinton Agar (MHA) and Mueller Hinton Broth (MHB) were purchased from Sigma Aldrich, Germany, while all other chemicals used were of technical grade. S. mutans was obtained from the Laboratory of Microbiology, Faculty of Pharmacy, University of Padjadjaran.

\section{Extraction}

The fruits of $\mathrm{BM}$ were dried in an oven at $50^{\circ} \mathrm{C}$, then extracted using $96 \%$ ethanol with a maceration



Cite this article: Budiman A, Aulifa DL. Antibacterial Activity and Mode of Action of Black Mulberry (Morus nigra) Fruits Extract Against Streptococcus mutans. Pharmacogn J. 2020;12(6) Suppl:1722-6. 
method thrice for 24 hours at room temperature. After which, the solvent used was removed by a rotary evaporator (IKA RV 10, IKA Company, Germany) at $50^{\circ} \mathrm{C}$ to obtain the crude extract.

\section{Phytochemical screening}

This was conducted to observe the presence of secondary metabolites such as alkaloids, tannins, saponins, quinones, steroids/triterpenoids, polyphenols, monoterpenes, and sesquiterpenes.

\section{Antibacterial activity}

This process was performed by using the disc diffusion method (Kirby Bauer). Furthermore, MHA was mixed with 5\% sterile sheep blood as a bacteria growth medium. S. mutans were dissolved in $0.5 \mathrm{McF}$ arland of Tryptic Soya Broth (TSB), and then poured into the media. The disc paper that soaked in the extract suspension with various concentrations was dried, then placed into the media, and incubated for about $24 \mathrm{~h}$ at $37^{\circ} \mathrm{C}$.

\section{Minimum inhibitory concentration (MIC) evaluation}

This was evaluated through the micro-dilution method using a microplate. $100 \mu \mathrm{l}$ of BM fruit extract with various concentrations was added into the media containing $100 \mu \mathrm{MHB}$. Ten $\mu \mathrm{l}$ of the bacterial suspension was adjusted to McFarland turbidity standards which have equivalence of $3.0 \times 108 \mathrm{CFU} / \mathrm{ml}$, followed by addition into each well of the media. Furthermore, the microplate was incubated at $37^{\circ} \mathrm{C}$ for $24 \mathrm{~h}$. Amoxicillin and 1\% v/v of Dimethyl sulfoxide (DMSO) solution were used as positive and negative controls, respectively. ${ }^{6}$

\section{Analysis of protein and nucleic acid leakage}

Ten $\mathrm{mL}$ of bacterial suspension grown in MHB medium for 24 hours was taken and centrifuged at 3500 RPM for $20 \mathrm{~m}$. The filtrate was discarded and the pellets in the tube were washed with a solution of phosphate buffer at $\mathrm{pH} 7$, then suspended in another $10 \mathrm{ml}$ of the buffer and shaken for $24 \mathrm{~h}$. Furthermore, BM fruit extract (with a concentration of $1 \mathrm{xMIC}$ and $2 \mathrm{xMIC}$ ) and control were added into the suspension. After which centrifugation was performed at 3500 RPM for $15 \mathrm{~m}$, followed by filtration to separate the supernatant and cells. The supernatant was analyzed spectrophotometrically at $260 \mathrm{~nm}$ and 280 nm (Shimadzu UV-VIS 1800). ${ }^{6}$

\section{Analysis of ion leakage}

The sample of the bacterial pellets was prepared using similar method with the proteins and nucleic acid that were analyzed. The leakage of cells was expressed with the presence of ions $\left(\mathrm{Ca}^{2+}\right.$ and $\left.\mathrm{K}^{+}\right)$in antibacterial activity evaluation, after BM fruit extract with $4 \times$ MIC concentrations was added. The leakage of the ions was determined by using Atomic absorption spectroscopy (Shimadzu). ${ }^{17}$

\section{Cell Morphological Observation}

A clear zone of the medium from the antibacterial test was soaked into a solution of $2 \%$ glutaraldehyde overnight as a sample. This was centrifuged and the supernatant was discarded. The residue was dispersed into solution of $2 \%$ tannic acid, then soaked for few hours, followed by centrifugation and disposition of the fixative solution. After that chocodylate buffer was added and soaked for $20 \mathrm{~m}$. The mixture was centrifuged and the supernatant was removed, then added $1 \%$ osmium tetraoxide, and soaked for $1 \mathrm{~h}$. The resulting mixture was again centrifuged, followed by discarding the supernatant, and the remaining sample was soaked in $50 \%$ alcohol for $20 \mathrm{~m}$. The residue was dried consecutively using $70 \%, 80 \%, 95 \%$, and absolute alcohol for $20 \mathrm{~m}$, respectively. Furthermore, the samples were suspended into butanol and soaked for $20 \mathrm{~m}$. The suspension were placed into the coverslip, subjected to drying, coated and observed using Scanning Electron Microscopy (SEM) (JEOL JSM-5310LV $\left.{ }^{\oplus}\right)^{18}$

\section{RESULT AND DISCUSSION}

The phytochemical screening of BM fruit extract was carried out as shown in Table 1. Flavoniods and phenolics which attributed to the antibacterial activity were observed. There were many compounds in the extract which belong to phenolic groups such as chalcone, kuwanon $\mathrm{E}$ and kuwanon $\mathrm{U}$, moracin, morusin, and anthocyanin..$^{19,20}$ In addition, they were predicted to be capable of denaturing bacterial cell proteins as well as inhibiting the cellular metabolism, while flavonoids and tannins can damage the walls.

The antibacterial activity of BM fruit extract was performed using the diffusion method as a result of being simple, rapid, inexpensive, and reproducible. ${ }^{21}$ This method is not suitable for natural waterinsoluble antimicrobial compounds, such as essential oil steroids and terpenoids due to impossiblity for them to homogeneously diffuse into the medium. ${ }^{22}$ DMSO was used to increase the diffusion rate with the suspension system. The MIC of the extract against $S$. mutans was $8 \mathrm{mg} /$ $\mathrm{mL}$, while the $\mathrm{MBC}$ was $16 \mathrm{mg} / \mathrm{mL}$ (Figure 1 ).

The leakage of cell will occur if the extract has antibacterial activity. Meanwhile, this could be detected spectrophotometrically at $260 \mathrm{~nm}$ and $280 \mathrm{~nm}$ for nucleic acid and protein, respectively. ${ }^{17}$ The result of the analysis can be seen in Figure 3. The amount of these molecules increases along with the concentration of BM fruit extract. When there is detection outside the bacterial cell, that indicates posibility of the extract to damage cell walls or change permeability of the membrane. The phenolics and flavonoids can diffuse through the membrane. This data is in agreement with the theory that flavonoids may demonstrate the antibacterial activity through the reduction of membrane fluidity causing fluid imbalance in the cells. ${ }^{23}$

The detection of metal ions such as potassium $\left(\mathrm{K}^{+}\right)$and calcium $\left(\mathrm{Ca}^{2+}\right)$ from bacterial cells could be attributed to the potential antibacterial activity of the compound. The $\mathrm{K}^{+}$plays an important role in the ribosome, while $\mathrm{Ca}^{2+}$ is needed as a component of the cell wall of gram-positive bacteria. ${ }^{24}$ The amount of $\mathrm{Ca}$ increases along with the concentration of BM fruit extract, while there was no significant change in the total $\mathrm{K}$ (Figure 3). Therefore, this result indicated that BM fruit extract can damage the cell wall and / change the membrane permeability. The $\mathrm{Ca}^{2+}$ can maintain the stability of the bacterial wall, while the release of these ions from the cell can disrupt the stability of bacterial wall and then resulting to death.

Morphological alteration was observed using scanning electron microscope. After treated the extract with 4 xMIC, the cell of $S$. mutans was shrinking due to degradation of the cellular membrane as shown in Figure 2. This result indicated that the fruit extract is a potential antibacterial activity agent.

Table 1: Phytochemicals Screening of BM Fruit Extracts.

\begin{tabular}{cc}
\hline Compound & Results \\
\hline Alkaloids & - \\
Flavonoids & + \\
Saponins & - \\
Polyphenols & + \\
Monoterpenoids and sesquiterpenoids & + \\
Tanins & + \\
Quinons & - \\
Steroids/triterpenoids & - \\
\hline
\end{tabular}



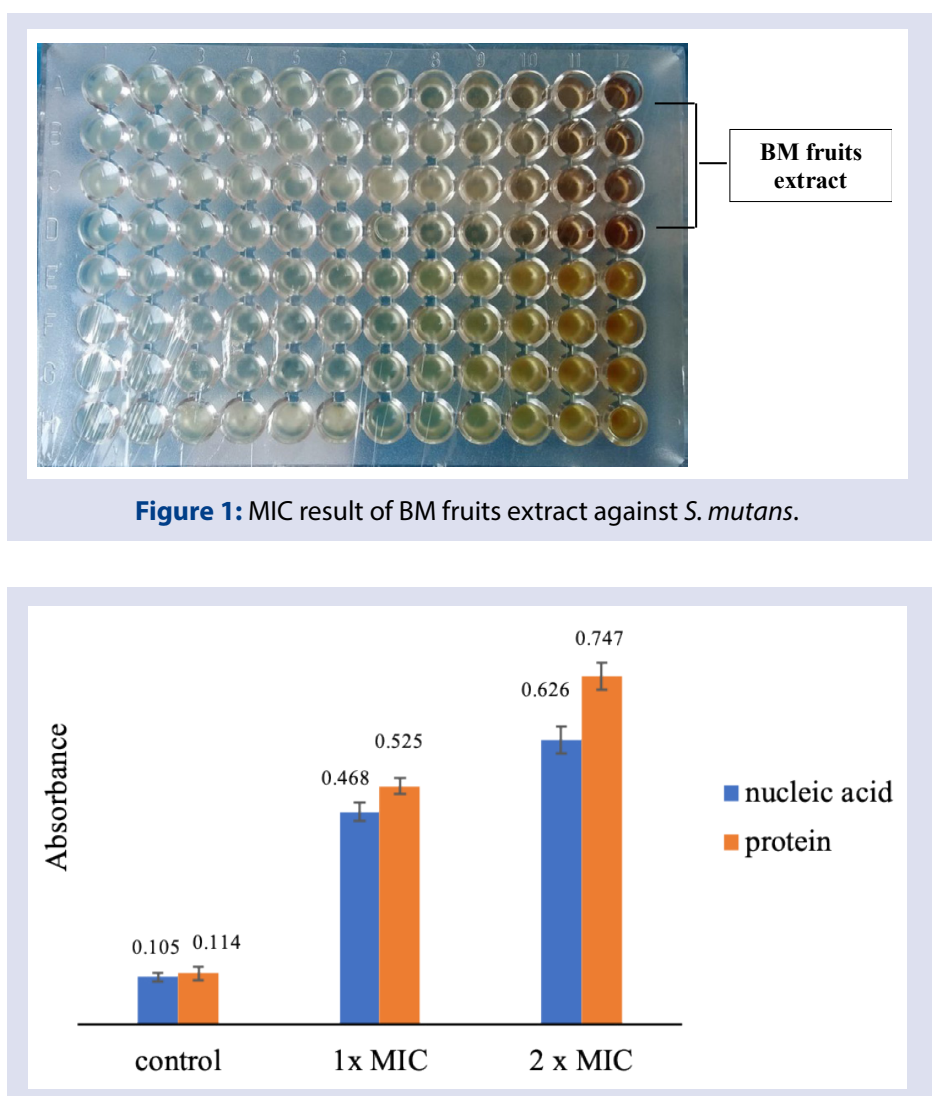

Figure 2: Nucleic acid $(260 \mathrm{~nm})$ and protein $(280 \mathrm{~nm})$ leakage with $1 \mathrm{xMIC}$ and 2xMIC of BM fruits extract against S. mutans.

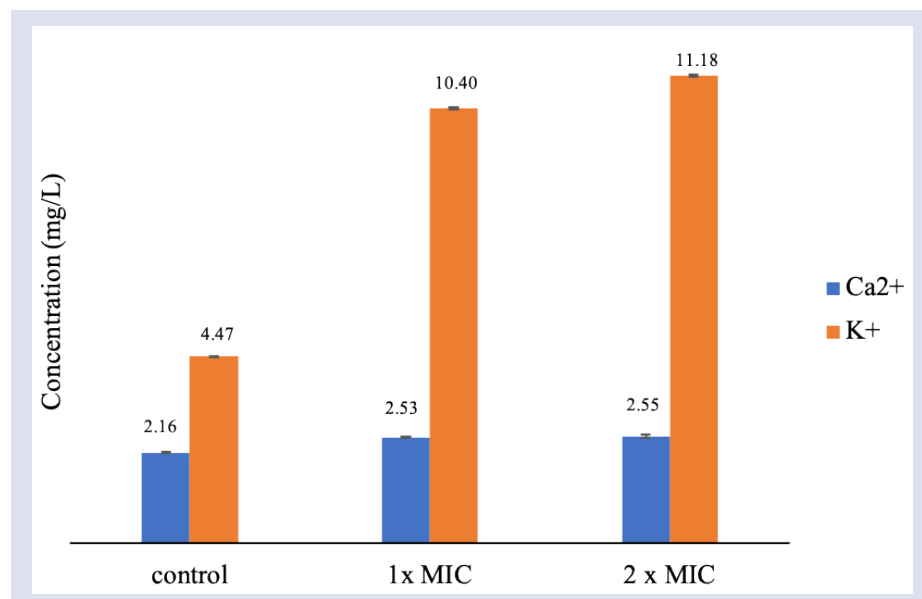

Figure 3. Absorbance of ions calcium $\left(\mathrm{Ca}^{2+}\right)$ and potassium $\left(\mathrm{K}^{+}\right)$with $1 \times \mathrm{MIC}$ and $2 x$ of BM fruits extract.

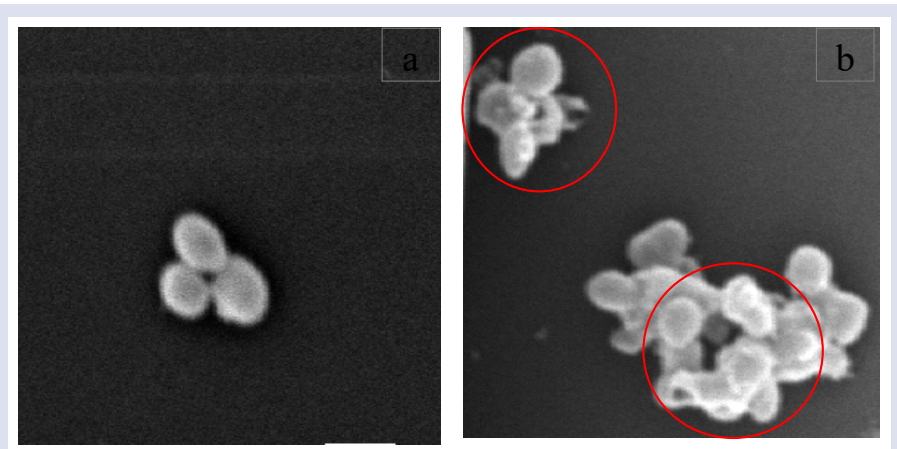

Figure 4: The cell morphology of S. mutans with scale in 10.000x (a) untreated, (b) bacteria treated with BM fruits extract $(3 \times$ MIC). 


\section{CONCLUSION}

The extract was found to be capable of inhibiting the growth of $S$. mutans. Based on the analysis of protein, nucleic acid, and ion leakage, as well as cell morphological observation, BM extract clearly exhibited the antibacterial activity with damage to the bacterial cell wall. Therefore, the results obtained indicated that the extract is a potential raw material for herbal medicines, especially anti-caries.

\section{REFERENCES}

1. Hussain F, Rana Z, Shafique H, Malik A, Hussain Z. Phytopharmacological potential of different species of Morus alba and their bioactive phytochemicals: A review. Asian Pacific Journal of Tropical Biomedicine. 7(10):950-6.

2. Natić MM, Dabić DČ, Papetti A, Akšić MM, Ognjanov V, Ljubojević M, Tešić ŽL. Analysis and characterisation of phytochemicals in mulberry (Morus alba L.) fruits grown in Vojvodina, North Serbia. Food chemistry. 2015;171:128-36.

3. Sánchez-Salcedo EM, Sendra E, Carbonell-Barrachina ÁA, Martínez JJ, Hernández F. Fatty acids composition of Spanish black (Morus nigra L.) and white (Morus alba L.) mulberries. Food Chemistry. 2016;190:566-71.

4. Wei H, Zhu JJ, Liu XQ, Feng WH, Wang ZM, Yan LH. Review of bioactive compounds from root barks of Morus plants (Sang-Bai-Pi) and their pharmacological effects. Cogent Chemistry. 2016;2(1):1212320.

5. Lim SH, Choi Cl. Pharmacological properties of Morus nigra L. (black mulberry) as a promising nutraceutical resource. Nutrients. 2019;11(2):437.

6. Aulifa DL, Fitriansyah SN, Ardiansyah SA, Wibowo DP, Julata YA, Christy DS. Phytochemical screening, antibacterial activity, and mode of action on Morus nigra. Pharmacognosy Journal. 2018;10(1):167-71.

7. Sofia PG, Ariana-Bianca V, Corina C, Gogoasa I, Corina G, Cerasela P. Chemical characterisation of white (Morus alba), and black (Morus nigra) mulberry fruits. J Horticultural Fore Biotech. 2014;18:133-5.

8. Radojković MM, Zeković ZP, Vidović SS, Kočar DD, Mašković PZ. Free radical scavenging activity and total phenolic and flavonoid contents of mulberry (Morus spp. L., Moraceae) extracts. Hemijska industrija. 2012;66(4):547-52.

9. Nakase K, Nakaminami H, Takenaka Y, Hayashi N, Kawashima M, Noguchi N. Relationship between the severity of acne vulgaris and antimicrobial resistance of bacteria isolated from acne lesions in a hospital in Japan. Journal of medical microbiology. 2014 May 1;63(5):721-8.
10. Budiman A, Aulifa DL, Kusuma AS, Sulastri A. Antibacterial and antioxidant activity of black mulberry (Morus nigra L.) extract for acne treatment. Pharmacognosy Journal. 2017;9(5):611-4.

11. Chen M, Xia L, Xue P. Enzymatic hydrolysis of corncob and ethanol production from cellulosic hydrolysate. International Biodeterioration \& Biodegradation. 2007; 59(2):85-9.

12. Souza GR, Oliveira-Junior RG, DinizTC, Branco A, Lima-Saraiva SR, Guimarães $\mathrm{AL}$, et al. Assessment of the antibacterial, cytotoxic and antioxidant activities of Morus nigra L.(Moraceae). Brazilian Journal of Biology. 2018;78(2):248-54.

13. Ryan KJ, Ray CG. Medical microbiology. McGraw Hill. 2004;4:370.

14. Loesche WJ. Role of Streptococcus mutans in human dental decay. Microbiological reviews. 1986;50(4):353.

15. Lamont RJ, Demuth DR, Davis CA, Malamud D, Rosan B. Salivary-agglutininmediated adherence of Streptococcus mutans to early plaque bacteria. Infection and Immunity. 1991;59(10):3446-50.

16. Tanzer JM, Livingston J, Thompson AM. The microbiology of primary dental caries in humans. Journal of Dental Education. 2001;65(10):1028-37.

17. Azifitria, Aziz S, Chairul. Antibacterial Activity of Ethanolic Extract of Leaves and Bulbs of Crinum asiaticum L. Against Acne-inducing Bacteria. Indones J Pharm. 2010;21(4):236-41.

18. Park KM, You JS, Lee HY, Baek NI, Hwang JK. Kuwanon G: An antibacterial agent from the root bark of Morus alba against oral pathogens. J Ethnopharmacol. 2003;84(2-3):181-5

19. Kim YJ, Sohn MJ, Kim WG. Chalcomoracin and moracin C, new inhibitors of Staphylococcus aureus enoyl-acyl carrier protein reductase from Morus alba. Biol Pharm Bull. 2012;35(5):791-5.

20. Qin C, Li Y, Niu W, Ding Y, Zhang R, Shang X. Analysis and characterisation of anthocyanins in mulberry fruit. Czech J Food Sci. 2010;28(2):117-26.

21. Klan A, Jer B, Smole S. Evaluation of diffusion and dilution methods to determine the antibacterial activity of plant extracts. 2010;81:121-6.

22. Mann CM, Markham JL. A new method for determining the minimum inhibitory concentration of essential oils. 1998;84(4):538-44.

23. Shashank K, Abhay K. Review Article Chemistry and Biological Activities of Flavonoids: An Overview. Sci World J. 2013;4(2):32-48.

24. Cox SD, Mann CM, Markham JL, Gustafson JE, Warmington JR, Wyllie SG Determining the antimicrobial actions of tea tree oil. Molecules. 2001;6(2):8791. 


\section{GRAPHICAL ABSTRACT}

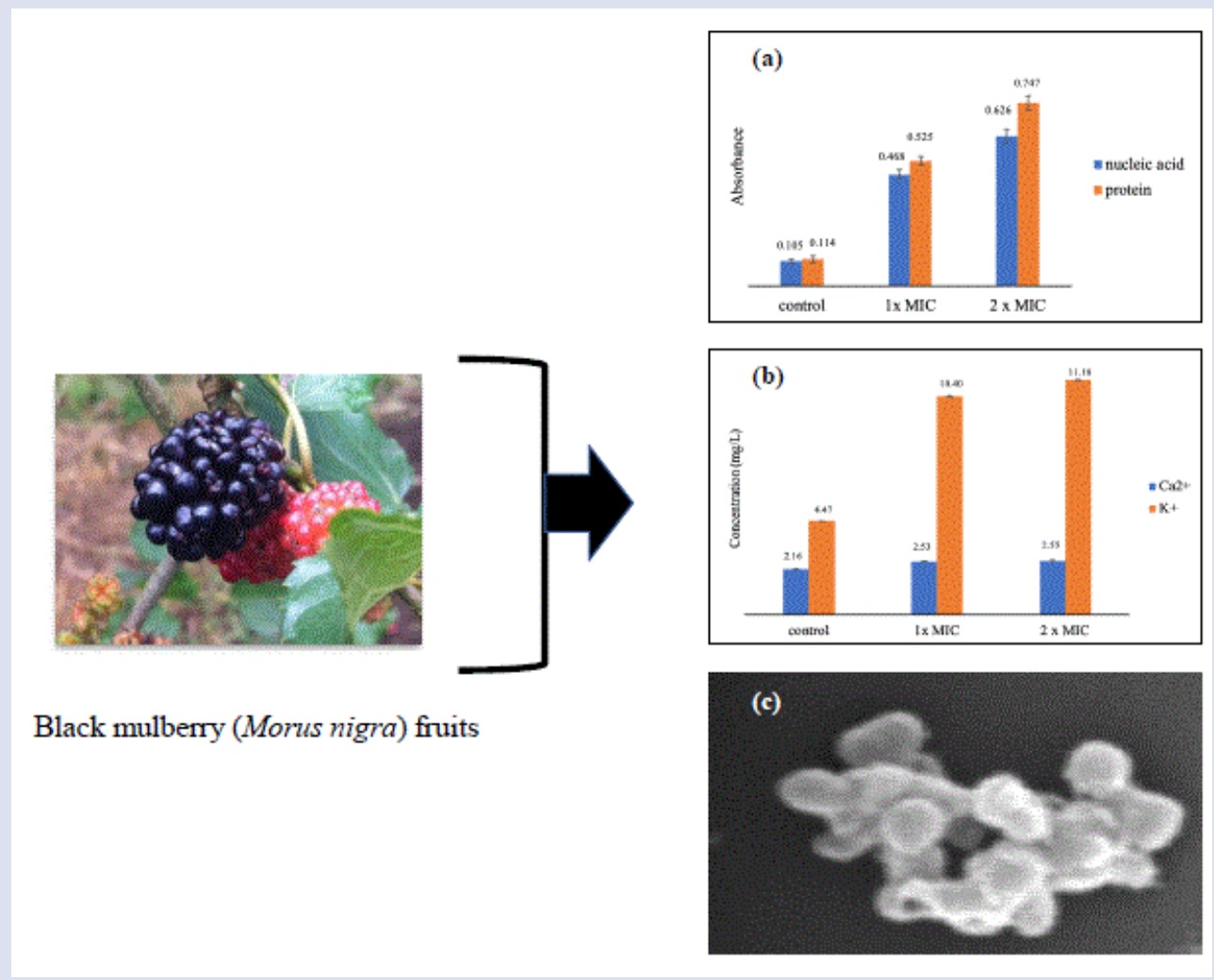

\section{ABOUT AUTHORS}

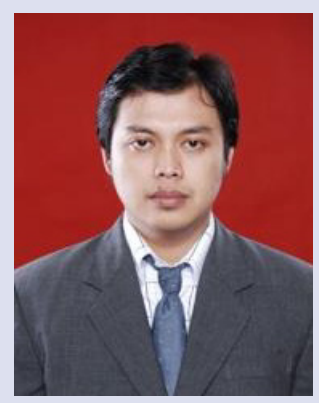

Arif Budiman is a lecturer in Department of Pharmaceutics and Pharmaceutical Technology, Faculty of Pharmacy Universitas Padjadjaran. Develop work in Physical Pharmacy and Pharmaceutical Dosage Forms Development.

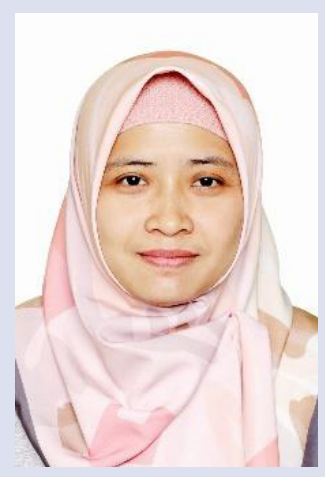

Diah Lia Aulifa is a lecturer in Department of Pharmaceutical Biology, Indonesian School of Pharmacy (Sekolah Tinggi Farmasi Indonesia), Bandung-Indonesia. Develop work in Phytochemistry and Phytotherapy from plants.

Cite this article: Budiman A, Aulifa DL. Antibacterial Activity and Mode of Action of Black Mulberry (Morus nigra) Fruits Extract Against Streptococcus mutans. Pharmacogn J. 2020;12(6)Suppl:1722-6. 